\title{
Terrorism and the information security of media content with special regard to ISIS, the Balkans and Russia
}

\author{
Csaba Kollár
}

Lecturer, National University of Public Services, Doctoral School of Military Engineering, Assistant Professor, Szent Istvan University, Faculty of Economics and Social Sciences, Hungary

\section{Zsuzsanna Vinárné Bellász}

Assistant Professor, Szent Istvan University, Faculty of Economics and Social Sciences, Hungary

\begin{abstract}
Terrorism in our days poses new challenges to the European governments and citizens as well, because it operates with new tools, much more professional leaders with presumably strategic thinking - compared to previous times - and with a communication activity involving the media, especially the electronic media. Out of the range of terrorist organizations, the present study chooses and discusses ISIS in detail. Although recently the citizens in Europe have also witnessed some terrorist acts, the large majority of them (fortunately) meet only the mediatized reality. However, the information content of news, fake news and hoaxes can often be questioned. The authors choose the transformation model from the communication models in order to demonstrate how many actors are needed to transfer the edited messages about terrorism, violence, suffering, etc. to the final (media) consumer, who can also act as a forwarder or sharer of messages. The model also reflects on the forwarders of messages related to terrorism as well as the main differences among shared topics. The categorized target groups consuming media content are also defined. The study also covers the ISIS message sent to the people in the Balkans and the target groups - which are supposed to be receptive to the message. Russia can also be an important factor in the war against terrorism - due to its world power status and geopolitical location - as it is discussed in the last section of the paper. The closing chapter of the study gives an analysis of the possible responses given by the European societies to the activities of terrorist organizations.
\end{abstract}

Keywords: terrorism, information security, media content, transformation model, Balkans, Russia.

JEL Classification: F5.

\section{Introduction}

There is no widely accepted definition of terrorism. The present paper uses two definitions based on the simple options that a Hungarian citizen with average knowledge has if he or she wants to find some information on the subject. According to the Wikipedia article "The terrorism is the strategy of using violence or threatening with violence in order to force well-defined political, ideological or religious objectives by generating fear". It should be added to this definition - as it will be later discussed in the study - that keeping the power is at least as important as forcing the objectives, especially in case of ISIS which is examined in this paper. Other important features are: the armed nature (traditional, biological, psychological or even information technology), taking hostages, (public) execution of hostages and sharing these videos through the media. Another widely available source is the Act $\mathrm{C}$ of 2012 on the Criminal Code. The acts of terrorism are described in Chapter 30, in Section 314. According to this, those persons commit terrorist acts whose aim is to „,coerce a government agency, another state or an international body into doing, not doing or countenancing something; intimidate the general public; conspire to change or disrupt the constitutional, economic or social order of another state or disrupt the operation of an international organization; ... or commit violent crime against specific persons, commit criminal offense that endangers the public or involves the use of arms".

It would be a mistake to say that the terrorism has brought fear into our life because the partial or total loss of our feeling of comfort (Balázs, 1997) coupled to security (e.g., becoming unemployed, illness, natural catastrophes directly affecting our life) can touch all of us even in "peacetime". The terrorists, however, gradually and deliberately exploit the fear in us and the related human reactions and they built their messages in major part of their media actions on these, especially when these are directed to the European citizens. 
The electronic media have an important role in modern terrorism (Taylor et al., 2014) because there are such shocking contents on display which destabilize the viewers both mentally and psychologically. Parallel with this it can be observed that the stimulus threshold of people has been permanently rising; the news and pictures, which used to be shocking, are often paired now with apathy or indifference, because some horror can be seen every day and people try to defend themselves psychologically. The other side, however, uses new communication catches every day, which are able to maintain the level of fear and dread.

In our days mostly only the Islamic extremists are in the public thinking, although there have been a lot of terrorist organizations on the European continent (and Great Britain), as well as in the USA and South America over the course of time: FRG - Red Army Fraction; Italy - Red Brigades; France - Action Directe; Ireland IRA; Spain - ETA; USA - Ku Klux Klan; Peru - Shining Path, just to mention the most widely known ones. Speaking about Islam, of course, we can associate to Fatah (1959), PLO (1964), Hezbollah (1982), Hamas (1987), Al-Qaeda (1988), Fatah al-Islam (2006), ISIS (2014). This latter (ISIS) is being engaged in very serious communication warfare parallel with "traditional" terrorism.

\section{Tactic and warfare of ISIS media}

Proxy warfare (Mumford, 2013) is something in which “... some third party participates as the delegate of great powers..." (Napoleoni, 2014). The author brings the Vietnam War as an example (1960s and 1970s). The given state may appear as a sponsor but sometimes they remain anonymous, use mediators for this purpose and make the peaceful ending of conflicts almost impossible, thus generating a real war (involving also the destruction of people, natural and built environment). Quite often the parties and the power relations are not clarified, sometimes new actors emerge. This type of warfare has not required any permissions, international approval or recognition so far. The core of this terrorism consists of people with strategic and tactical intelligence; their long-term strategy even includes the foundation and operation of a state. They are very difficult to defeat because - parallel with their religious fanatics - they are very conscious. It is legitimate to raise the question whether they can be defeated at all. Their way of thinking is hierarchic and complex at the same time, they often - practically - classify their supporters and enemies, and they even give special attention to the professionals of their future state (teachers, economists, doctors). They address the groups separately, they adjust the messages to them (examples will be given later on). Although it does not belong closely to this topic, but the role of oil (money, capital) should also be mentioned here. A number of experts (e.g.: Sugár, 2012) deal with the future role of this mineral, but it should be noted that these days only that state (formation) has a chance where oil rich sites can be found (on the basis of statistical data, ISIS received approx 1-2 million USD per day in 2014 from different - mostly "black" - oil transactions (e.g. it would be very interesting to find out the truth about the widely spread rumours related to the oil business coupled to Erdogan's son)).

In order to describe the communication tactic of ISIS-type terrorist organizations, the transformation model is applied, with the help of which this phenomenon can be analysed in a relatively objective way.

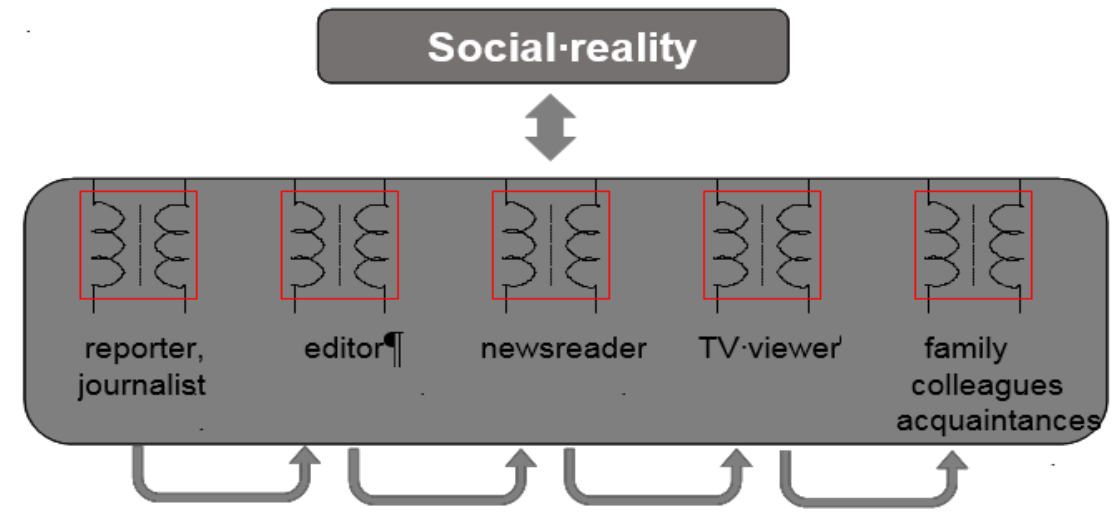

(media)·socialization·environment

Figure 1. The transformation model

The difficulty is in the fact that the reality can be analysed with the help of sociology of knowledge, but the mediatized everyday knowledge raises some problems (Cheatwood and Stasz, 1979; Waisbord, 2014; Berger, Luckmann, 1966). On the basis of "common sense" it can be declared that only the things experienced with our own senses can be really believed, but the greatest obstacle is that actually we rarely are in the physical 
location (fortunately or unfortunately). We are often forced to consider others' opinions. Looking at the actions in their course, first the reporter on the site faces the things. He or she prepares a subjectively transformed raw material for the editors (visuals, questions, etc.). The editor decides about further modifications (in what form and narration - newsreader - the report is broadcasted to the viewers). Thus the editor transforms again the already transformed material or text. The newsreader - within their own playing field - also passes the media content through their "subjective filter". The TV viewers also modify the news depending on their socialization and they probably share it in their own interpretation with family, friends, colleagues, or post the content on social media they use.

It is very interesting to see how much transformation and how many filters should the reality pass through (that is why the transformation model is so expressing).

The media channels of terrorists work very accurately, with visual and verbal contents edited by professionals. The lawyers often debate about these channels (international regulation). Most of the time, however, the process is stuck here because the legislators and law enforcers cannot really cope with the information technology and technical questions or problems.

\section{How the terrorists and their actions are covered}

Their material can be shared by the following:

1. Mass media: the editorial boards of mass media are responsible for the content on their media sites. The experts of ISIS often target social networking sites operating in Arabic language because practically these can be read in Europe only by people speaking Arabic. Their choice of topic is very conscious, the important information is provided in a mixture with horror. Their videos attract many viewers, not only those who are religiously committed, but also those who click on these sites out of curiosity.

2. Viewers: it is very difficult to define the category of the "viewers", but it can be declared that those who are aware of terrorist acts will become reporters or sharers. The visuals about terrorism and war have become the subject of public debate in Europe and USA, where people have become soft and accustomed to welfare and peace. On top of that, the terror attacks in these two continents have been rather frequent recently (USA: 11 September, 2001; London: 7 July, 2005; Paris: 7 January, 13 November, 2015; Brussels: 22 March, 2016; Nice: 16 July, 2016; Munich: 23 July, 2016. Not to mention Turkey: 7 June and 28 June, 2016). It is true that the response is not delayed but the responsible politicians do not always succeed in the fronts of psychological warfare (see the comments of social media sites!).

3. Own media workers: well-paid professionals (although for most of them the ideological commitment is also undisputable). Experts. They use their visual language; it is easily digestible for the viewers who have been socialized on films in Arabic language. The operate Jihadist web sites, Facebook, Twitter or YouTube sites and channels. They constantly upload the latest information.

4. Supporters: persons, who know social media well, are quick to share contents, evoke sympathy. The shares go viral which mean that the messages and contents reach many people very quickly. The supporters usually operate either in their own name but with minimum subjective information or as avatars who can be hardly identified, or sometimes anonymously. Their task is to shift the public mood in positive direction.

We can collect information about the terror attacks from a wide range of mass media. The "rationing" of contents strengthens the fear and the feeling of discomfort in the viewers. By using moving pictures, the TV and internet shows this frightening process, thus the horrendous effect is further strengthened. There is another big advantage compared to the "static" media (newspaper, journal, radio): the content, the information can be "consumed" at any time and - in theory - anywhere, in an interactive way.

If the topic is interesting, there is a lot of feedback, the interest can be maintained with new (information) "pieces". The result: more and more people will be interested in terrorism at some level (YouTube videos, documentaries, articles, books, etc.). The "snowball-effect" begins: the viewer strengthens their own dread, sometimes in a masochistic way. It can be culminated and reflected in the possible ways of solution: some of the viewers project their (verbal, sometimes physical) aggression against migrants, or can be radicalized by joining a terrorist organization (there are a lot of examples for both solutions in Western Europe and the USA).

The duality of the topic should also be mentioned: ISIS sends different messages to the West and to the East. The main message for the West is fear (horrendous footage of executions, etc.). This is enhanced by the figures of professional and dreadful warriors ("enhancement"). 
In addition to these, there are visuals about destroying the built and cultural heritage, which suggest that these are not valuable for the devout Muslims (Napoleoni, 2015).

The security and „we protect you" slogans dominate in the messages sent to the East, the people of Muslim religion. They also deliberately exploit the Eastern people's love of mysticism (e.g., the caliph of ISIS - Abu Bakr Al-Bagdadi is also such a well-built brand). ISIS draws up serious promises in their messages and says that the devout Muslims are loved and welcome back home to the land of their ancestors or to the areas conquered and administered by them. Part of Western European and North American Muslims could not fit in the culture which is strange to them; these messages are for them and for the enslaved local tribes. The "carrot", the appeal is well-organized public administration, social programs, "sharia", in general: simplified messages in a simplified language.

The target groups are as follows:

$>$ The radical Muslims are considered priority target group. They are approached with the image of an ideal Muslim empire and manipulated with the vision of a Muslim „Canaan”.

$>$ The less radical people and those living in the Western world form a separate group.

$>$ From a certain aspect they are considered apostates, religiously ,infected" because they live in non-Muslim countries; moreover (more or less) they have often settled in the society of the recipient country in existential and mental sense. The so-called "losers" should be mentioned separately: they have not integrated, not settled in the societies of Western civilization, they are frustrated, and therefore a Muslim caliphate $\mathrm{v}$ which offers existential and mental safety - is very attractive for them. However, not everybody is ready to sacrifice themselves for religious purposes, not everybody is ready to commit terror attacks. Primarily the young people remain in the crosshairs because they can be affected more easily (it was obvious from the recent terror attacks in Germany and France).

$>$ The different Mohammedan tribes and minorities (e.g. Sunnis) - as target groups - should be noted as well (Napoleoni, 2015). They are often at the periphery even in the Muslim countries; therefore they are more open to the promises of the caliphate.

$>$ Adventurers, mercenaries, as target group: if paid, they are ready for anything; they do not belong to anywhere in terms of ideology.

$>$ Target group of relatives: they are often motivated by personal revenge (see the "black widows" in Russia). The Muslim terror acts in Russia should be discussed separately because the role of women is very interesting. The Muslims (especially the men) are rather ambivalent towards this phenomenon.

$>$ Hostages, who are prone to Stockholm syndrome. After a while, hostages in a vulnerable situation often turn towards their captors positively, even with love. They become emotionally dependent, thus even supportive. Moreover, these „brainwashed” persons often commit terror acts themselves later.

$>$ Neighbouring Muslim countries: first of all Syria, Iraq, Turkey, or even Russia with its high number of Muslim population.

$>$ Western governments: ISIS generates and supports fear and intimidation by terror acts but there is another tendency in our days: ISIS claims responsibility for any kind of terror act that is committed (it is very difficult to look behind the scenes and we do not know how much is the truth and how much is the PR in these cases, and the picture is even more blurred by the problem of "sleeping cells"). The ISIS, by all means, uses info-terrorism in a professional way in this area, too.

$>$ The Balkan region forms a separate target group. We have to deal with these countries, too, because there are a lot Muslims living in this region in terms of religious affiliation, not to mention that Serbia and Croatia are neighbouring countries (common border $\approx 520 \mathrm{~km}$ ). ISIS very consciously communicates towards the Balkan countries.

The following countries are located on the Balkan peninsula: Albania, Bosnia-Herzegovina, Bulgaria, Kosovo, Macedonia, Montenegro, and some part of the following countries: Greece, Croatia, Romania (6\%), Serbia (73\%), Slovenia (27\%), Turkey (3\%).

By looking at the figures, it can be declared that the greatest Muslim communities live in Turkey, Kosovo, Albania and Bosnia-Herzegovina as regards the countries of the Balkan region. (Regarding the events of the recent weeks and months, Turkey is a special problem; it could be the topic of separate papers, just like Russia). ISIS uploaded a video on 10 June, 2015, titled: "We are the Islamic Caliphate". The recording was made in Bosnian language. The video reveals that in Europe the ISIS wants to expand in the Balkans the most aggressively and most 
dynamically. Their aim is to spread Islam in Serbia, to destroy democracy in Croatia and - very straightforwardly - to occupy areas in Montenegro. Tactically it was not a coincidence that the video was released on the 20th anniversary of the massacre in Srebrenica.

Table 1. Number of total, Christian and Muslim inhabitants in the Balkan countries

\begin{tabular}{|l|c|c|c|c|c|}
\hline \multicolumn{1}{|c|}{ Country } & No of inhabitants & $\begin{array}{c}\text { Number of } \\
\text { Christians }\end{array}$ & $\begin{array}{c}\text { Ratio of } \\
\text { Christians }\end{array}$ & No of Muslims & Ratio of Muslims \\
\hline Albania & 2.8 & 0.48 & $17.0 \%$ & 2.24 & $79.9 \%$ \\
\hline $\begin{array}{l}\text { Bosnia and Herze- } \\
\text { govina }\end{array}$ & 3.8 & 1.33 & $35.0 \%$ & 2.28 & $60.1 \%$ \\
\hline Bulgaria & 7.3 & 4.47 & $61.2 \%$ & 0.98 & $13.4 \%$ \\
\hline Greece & 11.1 & 9.93 & $89.5 \%$ & 0.52 & $4.7 \%$ \\
\hline Croatia & 4.3 & 4.06 & $94.4 \%$ & 0.13 & $3.0 \%$ \\
\hline Kosovo & 1.97 & 0.065 & $3.3 \%$ & 1.77 & $90.0 \%$ \\
\hline Macedonia & 2.1 & 1.33 & $63.4 \%$ & 0.73 & $34.9 \%$ \\
\hline Montenegro & 0.6 & 0.47 & $78.1 \%$ & 0.11 & $18.5 \%$ \\
\hline Romania & 21.3 & 18.71 & $87.8 \%$ & 0.06 & $0.3 \%$ \\
\hline Serbia & 7.1 & 6.52 & $91.8 \%$ & 0.23 & $3.2 \%$ \\
\hline Slovenia & 2.1 & 0.84 & $39.9 \%$ & 0.05 & $2.4 \%$ \\
\hline Turkey & 76.1 & 0.07 & $0.09 \%$ & 75.95 & $99.8 \%$ \\
\hline
\end{tabular}

Notes: The data are in million and in \%, from 2015, calculated data.

The Muslim people can interpret this message differently:

$>$ it is good news for the more radical ones;

$>$ it is an existential and mental possibility, the vision of a more liveable state for the frustrated Muslim.

On top of that, Europe (including the democratic states of the Balkans), which has become soft living in welfare, has no clear strategy in connection with the migrants. These governments - since they are democrats - could not allow locking these refugees into ghettos. It does not mean that all the migrants are terrorists but it is obvious that there are some deviant persons among the refugees, as it has been proved by the events of the recent weeks and months.

The situation is further complicated by the tensions among different Muslim groups (e.g., Bosnians versus Albanian Muslims).

International experts deny that there are a lot ISIS followers on the Balkans (approx. 10-15\% can be regarded radical) but the dangers should not be understated. ISIS poses very serious challenge. This terrorist organization addresses the younger generation (Muslim men aged 17-35) very efficiently. For them the ,holy war against the unbelievers" is especially glorious, that is why relatively many of them join the organization. Of course, it is not that simple for conspiracy reasons. The official position of ISIS leaders is that the faithful people should be integrated in the organization, but the candidates have to submit a detailed ,portfolio": plans of military actions; project of public administration and social system.

It also proves that the future strategy of ISIS is the following: an autonomous area organised and administered on religious basis, in longer term: founding a European Islamic state. Tactic: ISIS attacks in multiple fronts; terror attacks in the heart of Europe (Belgium, France, Germany); taking small but rather effective steps in countries with (relatively) high number of Muslim population.

Countries like Russia are especially interesting. Following the first (11 December, 1994 - 31 August, 1996) and the second Chechen war (26 August 1999 - April 2009 with continuing attacks up until today) there have been several terror attacks all over Russia. The casus belli of the second Chechen war was that Chechen commander S. Basayev, and Saudi Arabian chief Ibn-el-Hattab, occupied several villages in Dagestan with some 2000 fighters. They wanted to separate this area from Russia and declare an Islamic republic there. The counterattack of Russians arrived without delay but the local people did not fully support the „initiative” either. Parallel with the military actions, a number of terror attacks were also committed. The most wellknown are: 2002 - Dubrovka Theatre in Moscow; 1 September, 2004 - Beslan, opening ceremony at a school (186 children were killed). For the first time, the Russian people saw videos about beheading people and there was a specific Chechen phenomenon, the "black widow" (personal revenge). 
In summer 2016, the Duma - at first reading - has adopted the so-called "Yarovaya anti-terrorist package", but it raises a number of legal and financial problems: interceptions, restrictions of the Internet, administrative actions against civil initiatives, etc. That is why the opposition protest or try to protest, with little effect (e.g., the anti-Kremlin protest rally convoked in Moscow for 27 July, 2016 was banned by the authorities) (Kommersant.ru).

\section{What are the options of European societies against ISIS (and the other terrorist organizations)?}

The European societies are basically not prepared for a unified defence. The people have "elaborated" a lot of survival strategies. The following action ,strategies” were mentioned in a focus group discussion with 12 people (Kollár, 2015):

a) The "indifferent", "ignore-the-whole-thing" type: they consciously protect their nervous system from these topics. Of course, they cannot exclude the outside world altogether, but they immediately change the subject when issues of terrorism are raised;

b) Those, who understate: it is a protecting mechanism as well, it is based on the psychological process that - in theory - if we make our enemies insignificant we can overcome them;

c) The terrorists are ridiculed: it is again a self-deception, because by making fun of our enemies we may feel - but only in our heads - that they are defeated. The cartoonists of Charlie Hebdo are good example for this. Typical examples of irony, "wittiness", black humour can be found in the comments, too;

d) Supporters: there are two types. The first type makes friends with those who represent the given ideology often because they think that they can protect themselves by making friends (there are a number of examples in criminalistics which prove that it does not mean real protection in most of the cases). Those belong to the other group who are committed: they regularly attend the gatherings, they become Muslim or they give financial support to the given ideological group;

e) Opposition: the more peaceful members of a given society urge national and international intervention. These persons use the available tools: open letters, sharing these letters on social media, organization of groups with people thinking similarly, submitting petitions, blogs, etc. More aggressive members of the society commit physical actions: they ravage mosques, insult Muslim-looking people, etc.

f) Own safety is appreciated: many people follow the "my house is my castle" principle and they install more serious alarm systems in their houses (cars), avoid the dangerous cities or parts of cities.

g) There are fatalists or resigned: "What can we do? Nothing. Such is the world."

h) Many people are thinking about the problem and try to set up a cause-and-effect chain and urge some rational solution ("problems should be solved locally on site", "why Islam has become so aggressive?");

i) Media counter-attack, information warfare: the conflicting groups have recognized how dangerous weapon is the mass communication and the traces of info-war can be seen on the social network every day. Professional hacker groups have also joined the war (e.g., Anonymous, which fights against ISIS by hacking their websites, discrediting the leaders of the organization);

j) "Intellectual supporters": one of the defence mechanisms, they study Koran and research the references.

\section{Conclusion}

The introduction of this study discusses terrorism in general and it points out - with the help of the transformation model - that terrorists use the media in their communication campaigns more and more frequently and professionally. Media - especially mass media - have become part of the terrorists' psychological arsenal. As regards ISIS, the IT warfare, professional tactic and strategy of the organization have been discussed.

ISIS is a permanently changing organization, and as regards their operation, only predictions can be drawn up. ISIS would like to create safety by launching war (against the Western civilization) and it is very likely that the number of terror attacks will not decline but probably increase, including European locations as well, which have been regarded basically safe so far.

In our opinion, however, Islam as religion and terrorism cannot be and should not be equated, but the reaction of the society - which starts to think that those who/what are „Islamists” (including e.g., the external traits or the language) can be terrorists - can be regarded normal. This process is further strengthened by the information security - or rather information insecurity - of mediatized contents. The Islamist (Lewis \& Churchill, 2009) and the Christian/Jewish culture - although the basic principles are the same in many aspects - follow substantially different paths in the practice. It is a question if these paths may have some meeting points (e.g., receiving refugees) which do not hide any unexploded - actual or symbolic - landmines. 
About the authors

Csaba Kollár communication technology engineer; Ph.D. of Economic Sciences; coach; consultant; data protection, information security and economic mediator. Lecturer at the Doctoral School of Military Engineering of the National University of Public Administration and Szent Istvan University; works in a family venture.

Zsuzsa Vinárné Bellász graduated from Eotvos Lorand University Faculty of Arts, major in Philosophy and Russian, and from the Szent Istvan University, major in settlement development. Her field of interest is ethics, international terrorism (especially Russia) and analysis of reactions from society to terror attacks.

\section{References}

\section{Printed}

1. Mumford, Andrew (2013). Proxy Warfare. Malden, Polity Press.

2. Lewis, Bernard-Churchill, Buntzie Ellis (2009). Iszlám. Nép és vallás. Budapest, HVG Kiadó.

3. Balázs Judit (1997). A gazdasági biztonságról. Budapest, Stratégiai és Védelmi Kutatóintézet.

4. Berger, Peter L. -Luckmann, Thomas (1967). The Social Construction of Reality, New York, Anchor Books (reprint, eredeti kiadás: 1966).

5. Cheatwood, Adrian Derral-Stasz, Cathleen (1979). Visual sociology. In: Wagner, Jon (1979 szerk.) Images of Information. Beverly Hills, Sage 261-269.

6. Kollár Csaba (2014). Cheatwood és Stasz vizuális szociológiájának marketingkommunikációs vetületei. FLUENTUM nemzetközi gazdaság- és társadalomtudományi folyóirat, 2014. I/4.

7. Kollár Csaba (2015): A média veszélyes fegyver, és van, aki fegyvertelen. A médiaeszközök használata a terrorizmusban, különös tekintettel a modern kommunikációs eszközökre és technikákra. In.: JELKÉP, 2015/3. szám, 65-75.

8. Napoleoni, Loretta (2015). Az iszlamista fönix. Az Iszlám Állam születése és a Közel-Kelet újrafelosztása. Budapest, HVG Kiadó.

9. Sugár András (2012). Változik-e a kőolaj szerepe a világgazdaságban és Magyarországon? Közgazdaság, 2012. 7 (2). 79-94.

10. Taylor, Rober W.-Fritsch, Eric J.-Liederbach, John (2014). Digital Crime and Digital Terrorism. London. Prentice Hall.

Electronic

ISIS - On the frontline. Ahlulbayt TV, released: 27 February 2015.

https://www.youtube.com/watch?v=rtZN652OAoISIS - „Islamic” Extremism? Ahlulbayt TV, released: 2 December, $2014 \mathrm{https} / / / \mathrm{www}$. youtube.com/watch?v=WVMFnESN1fg.

Havasi Z. (no date): A terrorizmus és a jog. http://zmne.hu/dokisk/hadtud/havasi.pdf.

http://hu.wikipedia.org/wiki/Terrorizmus.

I am a muslim. I am labelled a terrorist. Hug me, released: 12 February 2015. Retrieved from https://www.youtube.com/watch?v=aysp_WdaNFA.

Kasparov.ru.

Kommersant.ru.

Nol.hu/kulfold/bosszubol-olnek-a fekete-ozvegyek-1577439. 